\title{
Privatised Keynesianism: An Unacknowledged Policy Regime
}

\author{
Colin Crouch
}

\begin{abstract}
There have now been two successive policy regimes since the Second World War that have temporarily succeeded in reconciling the uncertainties and instabilities of a capitalist economy with democracy's need for stability for people's lives and capitalism's own need for confident mass consumers. The first of these was the system of public demand management generally known as Keynesianism. The second was not, as has often been thought, a neo-liberal turn to pure markets, but a system of markets alongside extensive housing and other debt among low- and mediumincome people linked to unregulated derivatives markets. It was a form of privatised Keynesianism. This combination reconciled capitalism's problem, but in a way that eventually proved unsustainable. After its collapse there is debate over what will succeed it. Most likely is an attempt to re-create it on a basis of corporate social responsibility.
\end{abstract}

Keywords: privatised Keynesianism; financial crisis; corporate social responsibility; capitalism and democracy

There have now been two successive policy regimes since the Second World War that have temporarily succeeded in reconciling the uncertainties and instabilities of a capitalist economy with democracy's need for stability for people's lives and capitalism's own need for confident mass consumers. The first of these was the system of public demand management generally known as Keynesianism. The second was not, as has often been thought, a neo-liberal turn to pure markets, but a system of markets alongside extensive housing and other debt among low- and medium-income people linked to unregulated derivatives markets. It was a form of privatised Keynesianism. This combination reconciled capitalism's problem, but in a way that eventually proved unsustainable.

Following the fall of communism at the end of the 20th century it became common to equate capitalism with democracy (Fukuyama 1992). The equation was strengthened by a growing and historically novel preference of governments in the United States for the regimes they supported in Latin America and to a lesser extent the Arab world to submit themselves to periodic re-election. The spread of markets, giving consumers freedom of choice in the economy, seemed to go alongside the spread of voting procedures giving citizens choice in the polity. Further, and somewhat less convincingly, because dictatorships involved 'big government', democracy was considered to produce polities within which citizens would ask governments to do less and, by implication, markets to do more.

This was a very different perspective from that of capitalist thinkers of the 19th century, for whom there was a fundamental distinction between liberalism and 
democracy. By liberalism they understood a polity of free and open debate, with government strictly answerable to an electorate of citizens, but with citizenship limited to men owning property above some specified level. Douglass North (1990) has shown how it was precisely political regimes based on such restricted citizenship that had produced the legal basis of market capitalism in the 18th century. In fact, the property-owning elite of that period had come from an even more restricted landowning oligarchy than envisaged by 19th-century thinkers. As North points out, the rules of the market depend primarily on the protection of property rights. In the first instance this protection was against the king or other sovereign political power, who had to be persuaded not to interfere with property rights or restrict trade by granting monopolies (Wensley (forthcoming)). But equally, and increasingly during the course of the 19th century, property owners sought defence from interference in their rights by the property-less, the great mass of the population. Democracy was the potential enemy of the capitalist economy. As political movements representing the industrial working class gravitated towards Marxist ideas, these fears became very real. Often property owners decided that, if forced to choose between an anti-liberal regime that would still defend property rights and a liberalism that was sliding towards democracy, they would prefer the former. During the 1920s and 1930s this led many to make a further compromise, preferring the demotic anti-liberalism of fascism and Nazism, antithesis though that was to 19th-century liberalism, to a democracy that increasingly seemed to imply Bolshevism.

How the fraught relationship between capitalism and democracy changed until the words could be used as virtual synonyms by some commentators is a long and complex story. Part of it has to do with the role of US advertising, market research and communications sciences in enabling elites both to talk and listen to the masses-a skill that until the mid-20th century only leaders of the left, extreme left and extreme right seemed to possess. But I want here to concentrate on a part of the story that is relevant to macroeconomic policy.

One of the reasons why 19th- and early 20th-century elites took a fearful and pessimistic view of democracy was that they could not see how mass prosperity could be achieved quickly enough to satisfy the demands of a literally hungry populace before the anger of that populace would have dismantled property rights. The more optimistic, such as the British, saw hope in a gradual simultaneous expansion of both property ownership and citizenship, the former being aided by the growing wages and stability of skilled manual workers, the increasing ranks of office workers, and phenomena like the building society movement that spread residential property ownership.

But the problem was not only that workers were poor and lacked property. Their lives were also deeply insecure, as the growing market economy was subject to wide fluctuations. Early social policy, starting in Germany and gradually spreading to France, the Austrian empire, Britain and elsewhere tried to put a basic floor under this insecurity, but its ambitions and therefore its achievements were limited.

A more substantive answer to the poverty problem came in the early 20th century from the mass production system of manufacture associated initially with the Ford 
Motor Company in the USA. Technology and work organisation could enhance the productivity of low-skilled workers, enabling goods to be produced more cheaply and workers' wages to rise, so that they could afford more goods. The mass consumer and mass producer arrived together. It is significant that the breakthrough occurred in the large country that came closest to a basic idea of democracy (albeit on a racial basis) during that period. Democracy as well as technology contributed to construction of the model. However, as the Wall Street crash of 1929 , coming just a few years after the launch of the Fordist model, showed, the issue of insecurity remained just as great. The problem of reconciling the instability of the market with consumer-voters' need for stability remained unresolved. In much of Europe tendencies towards both communism and fascism were strengthened.

By the end of the Second World War it was clear to elites throughout the then industrialising world that the attempt to defend property from democracy through fascism had been a disaster. Capitalism and democracy would have to be interdependent, at least in those parts of the world where popular movements could not easily be resisted. The virtuous spiral of the US Fordist model of mass production technology linked to rising wages and therefore to rising mass consumption and more demand for mass-produced goods was part of the answer. The more extensive approach to social policy of the kind emerging in the Scandinavian and British welfare states addressed the problem of insecurity. Confident, secure working-class consumers, far from being a threat to capitalism, could enable an expansion of markets and profits on an unprecedented scale. Capitalism and democracy became interdependent. Elements of the same solution were also pursued in the state socialist economies dominated by the Soviet Union, but without democracy or capitalism. Fordist and Taylorist production methods were adopted enthusiastically; and considerable security was imparted to workers' lives by both a welfare state and a closed, state-controlled economy that simply did not allow exogenous shocks to disrupt economic activity. This approach eventually stored up such unresolved distortions that the system stagnated and lost its capacity to produce prosperity. For present purposes we shall concentrate on the 'western' story, that of countries that, in contrast with the Soviet bloc, sought increasing prosperity by gradually opening their markets— to trade, competition and exogenous shocks.

In those countries where capitalism was moving into full partnership with electoral democracy, it was acquiring a new vulnerability. In a fully free market, wages and employment were likely to fluctuate; would workers, who were dependent on their incomes for their level of living and lacked the cushion of wealth of propertied classes, be confident enough to consume at levels adequate to enable capitalists themselves to sustain confidence to invest and maintain profit levels? Would the very characteristics of the market that constituted its strength-flexibility, especially of labour-undermine its own ability to thrive? It should be noted that we are not here talking of the market producing social problems of insecurity in workers' lives-that might be dealt with by an adequate welfare state-but of its producing problems for itself through its own dependence on workers' willingness to maintain and increase their consumption. It can be assumed that the level of living at which social policy will sustain purchasing power will be below that needed to sustain an expanding, consumption-driven economy. 
According to neo-classical theory the problem should be a minimal one: if markets are genuinely free, adaptation to shocks is rapid. Further, the only shocks are exogenous ones, since the constant, microscopic adjustment to endogenous changes that takes place in pure markets prevents anything like a 'shock' from developing. There were several reasons why the problem could not be resolved that way. First, markets in the post-war economy did not start from a position of 'purity'. Even if it is true that there are no endogenous shocks in a pure market, the process of achieving a pure market from a starting point in a highly impure one includes plenty of shocks. Second, while it might be assumed that the fully informed, rationally calculating actors envisaged by economic theory might appropriately discount past shocks when planning future expenditure, there are strong reasons to believe that ordinary consumers do not act that way. Their knowledge of likely futures is highly defective; their capacity to take financial risks is very low. Their most likely guide to the future is likely to be their experience of the past, and they will err on the side of risk aversion when making their judgements. The adult generations of the post-war period, with their experience of two world wars and a major world slump, were likely to be particularly risk averse.

Partly consciously, partly accidentally, economic and political elites fell into various different approaches to solving this dilemma between capitalism's simultaneous needs for labour flexibility and consumer confidence. The most obvious solution was for labour and consumers to be broadly two different groups. This could be achieved through export-led growth. The national workforce would not enjoy security, but national capital would not depend on its consumption, but on that of workers in countries with different economic circumstances. The main exemplar of this model was the early history of the new western Federal Republic of Germany; another, broadly but not completely similar, was Japan. Wartime destruction, the arrival in the country of millions of Germans expelled from Eastern Europe and a currency reform that drastically reduced the purchasing power of the Deutschmark all kept labour highly flexible and workers poor. But the undervalued Mark enabled Federal Germany to gain a strong export position. German democracy could stand the strain of this because the people were recovering from years of Nazi dictatorship, defeat in war and the partition of the country. There was little appetite for causing anti-capitalist disruption, especially given how the anti-capitalist East German regime was treating its people.

As the years passed the German (and Japanese) models changed. A strong welfare state and various forms of labour protection supported a gradual and eventually powerful rise in consumer confidence and strong home markets. But a strong orientation to export-led growth alongside a potentially vulnerable consumer confidence has continued to mark these countries' economies.

In a second model markets were not liberated as extensively as in Germany. France and, to a lesser extent Italy, are major examples. The state provided important elements of security for employment in key industries and firms, including important state-owned ones. It also protected agriculture, in which many people were still employed. In France there was also an important role for social policy guaranteeing basic security; in Italy strong families were more likely to play this part. Large parts of the economy, primarily small firms and sectors in light industry 
considered non-strategic were excluded from the model, providing an enormous buffer of flexibility. Workers in these industries were therefore left outside the model. In France the state played a sufficiently large social policy role to maintain income for them. This was not the case in Italy, but there many of those in the non-strategic sectors were working in the specialised industrial districts of the centre and north-east. These gradually developed their own niches that combined flexibility with some security. In an industrial district, unless the whole industry collapses, there are usually new job opportunities within easy reach if an individual firm collapses. Meanwhile enough people were included in national champion sectors for national capitalisms to avoid the dilemma between the need for labour flexibility and the need for consumer confidence.

A third model could be seen in the Scandinavian countries, the UK, Austria and, to a lesser extent, the USA. It is generally known as Keynesian demand management, after the British economist John Maynard Keynes. In times of recession, when confidence was low, governments would go into debt in order to stimulate the economy with their own spending. In times of inflation, when demand was excessive, they would reduce their spending, pay off their debts and reduce aggregate demand. The model implied large state budgets, to ensure that changes within them would have an adequate macroeconomic effect. For the British and some other economies this possibility occurred only with the vast rise in military expenditure required by the Second World War. Previous wars had seen large rises in state spending, always followed by a major reduction afterwards. The Second World War was different, in that military spending was replaced by that on the new, growing welfare state.

The Keynesian model protected ordinary people from the rapid fluctuations of the market that had brought instability to their lives, smoothing the trade cycle and enabling them gradually to become confident mass consumers of the products of a therefore equally confident mass-production industry. Unemployment was reduced to very low levels. The welfare state not only provided instruments of demand management for governments, but also brought real services in areas of major importance to people outside the framework of the market: more stability. Armslength demand management plus the welfare state protected the rest of the capitalist economy from both major shocks to confidence and attacks from hostile forces, while the lives of working people were protected from the vagaries of the market. It was a true social compromise. As conservative critics pointed out from the start, there was always likely to be a ratchet effect in the mechanism: it was easy for governments to increase spending in a recession, bringing lower unemployment, more public services and more money in people's pockets. It would be far more difficult at times of boom in a democracy to reverse these trends. This was the seed of destruction at the heart of the model. We shall come to it shortly.

While Keynesian policies were adopted in only a few countries, they had important international effects, mainly because of the dominance of the US economy. It was US consumers, and to some extent those in the other Keynesian countries, who bought the exports of Germany and other countries with weaker domestic markets. In addition, the vast injections of Marshall Aid from the USA which benefited nearly all of non-communist Europe, and the similar assistance extended to Japan, 
meant that public spending-in this case another country's public spendingfurther stimulated these economies and maintained the security of working people's lives. Germany's own formal economic policy stance depended on balanced budgets, an autonomous central bank and a high priority on avoiding inflation. But during this period the German economy depended for its stability, not on pure markets, but on a general Keynesian environment. For this reason the post-war epoch, stretching roughly three decades into the mid-1970s, or what the French call les trente glorieuses, is often, albeit rather sloppily, called the Keynesian epoch.

Germany was not however an outlier in a further ingredient of the post-war demand management model: neo-corporatist industrial relations (Lehmbruch and Schmitter 1982; Crouch 1993; Traxler et al. 2001). This had not been anticipated in Keynes' own writings, and it featured hardly at all in US and only fitfully in British approaches; but it was fundamental to the Nordic, Dutch and Austrian cases. Under neo-corporatist industrial relations trade unions and employers' associations have regard to the impact of their agreements on labour costs on the general level of prices, and particularly on export prices. This can work only if these organisations have sufficient authority over all firms to ensure that the terms of the deal are not significantly broken. The countries listed, where this kind of collective bargaining has been particularly important, are all small economies, heavily dependent on foreign trade. Broadly similar arrangements developed in Germany, the only large country involved, as part of the priority on export- as opposed to domestic-led growth of that economy. Further, in Germany the union movement has been dominated by one large organisation in the mining, steel and engineering sectors and therefore is particularly sensitive to export prices.

The importance of neo-corporatism for present purposes is that it addressed the Achilles' heel of Keynesianism: the inflationary tendencies of its politically determined ratchet. Countries that had Keynesian policies but no or weak neo-corporatism-before all others the UK and (though with less reliance on Keynesianism) the USA, but by the 1970s France and Italy too-were highly vulnerable to the inflationary shocks unleashed by the general rise in commodity prices during the 1970s, particularly the oil price rises of 1973 and 1978 (Crouch 1993, ch. 7). The wave of inflation that then affected the advanced countries of the west, though nothing like what had been experienced in Germany in the 1920s, or in various parts of Latin America and Africa more recently, more or less destroyed the model-though with different responses depending on different experiences with the Keynesian model itself.

\section{On to Privatised Keynesianism}

An intellectual challenge to Keynesianism had long been ready. The advocates of a return to 'real' markets had never ceased to be active, and a range of policies was in readiness. The key objective was to have governments withdraw from accepting overall responsibility for the economy. While for the purposes of this article we are concentrating on demand management, Keynesianism had become emblematic of a far wider range of policies of regulation, welfare provision and subsidy. Combined with Fordist production systems, the model now appears to characterise a particular 
historical period and a stage in the development of capitalism, or a distinctive accumulation regime (Boyer 2004a, 2004b and 2005). Seen from one perspective (Giddens 1998) it was suited to a mass industrial working class producing standardised goods and accepting standardised government and welfare services. This was not just a production regime, but virtually an entire society.

Karl Marx famously wrote that at particular moments of historical crisis particular social classes were in a position where their particular interests coincided with the general interest of society. Such classes triumphed in the revolutions in which the crises ended. Marx's error was to believe that when the class concerned became the international proletariat there would be an end to the process, because the proletariat was the generality of society and not just a particular interest within it. This was an error if only because it is impossible to imagine anything as vast as the global proletariat producing organisational forms that could express a shared interest. In reality the proletariat appeared on the stage of political history in national packages, oriented towards the political possibilities presented by individual nation states. Be that as it may, the Keynesian model did represent a temporary coincidence between the interests of the industrial working class in the global north-west and a general interest of the politico-economic system. This was the class likely to threaten political and social order. It was also potentially the class whose mass consumption, if facilitated and made secure, could fuel economic growth of a kind unprecedented in human history. Finally, it was a class that had produced political parties, trade unions and other organisations, as well as associated intellectuals, to shape and press its demands. The Keynesian model, combined with Fordist production, was a response to these demands that reconciled them with a capitalist system of production.

The opposing set of free-market ideas required a historical moment to justify their installation in the approaches of governments and international organisations. The 1970s' inflationary crisis provided this. Within a decade or so such ideas as the absolute priority of near-zero inflation at whatever cost in terms of unemployment, the withdrawal of state assistance to firms and industries in difficulties, the priority of competition, the predominance of a shareholder maximisation as opposed to a multiple stakeholder model of the corporation, the deregulation of markets and the liberalisation of global capital flows had become orthodoxy. Where governments in countries with weak economies were unwilling to accept them, they were imposed as conditions for assistance from or membership of such international bodies as the International Monetary Fund, the World Bank, the Organisation for Economic Co-operation and Development (OECD) or the European Union. When the Soviet Union collapsed in 1989, the more westerly of its former allies were brought within the scope of the new model through the assistance offered by these international organisations.

A further change that had taken place in the meantime was the declining autonomy of the nation state. The post-war political economy had been founded on the basis of governments that could exercise considerable discretion in how they managed their economies. By the 1980s the process generally known as globalisation, both a producer and a product of the deregulation of financial markets, had eroded much of that autonomy. The only actors capable of rapid action at global level were 
transnational corporations (TNCs), who preferred their own private regulation over that by governments. This both advanced and even rendered necessary the new model-even though tensions remained and remain unresolved as to how marketdominant oligopolistic corporations could be consistent with the concept of regulation by near-perfect markets.

Just as a class - that of industrial workers - can be seen as the bearers of the Keynesian model, so we can identify a class whose particular interests seemed to embody the general interest in the new model: the class of finance capitalists, geographically grounded primarily in the USA and the UK but extending across the globe. If the world was to gain from the liberation of productive forces and enterprise that the spread of free markets would bring, the class of those who dealt in the unregulated finance that massaged and helped those markets to grow would benefit particularly. Whereas the tight labour markets and regulated capitalism of the Keynesian period had seen a gradual reduction in inequalities of wealth in all advanced countries, the following period was to see a reversal of these trends (OECD 2009), with the highest rewards going to those working in financial institutions.

Two questions are immediately raised by this history. First, what had been the fate of the industrial working class, whose interests had seemed so politically urgent in the 1940s and 1950s? And what had become of the need to reconcile the instability of markets with people's demand for security in their lives, which had been, both politically and economically, so important?

The initial crisis of Keynesianism in the 1970s had been accompanied by an extraordinary wave of industrial militancy, such that one might have thought that the challenge of that class was becoming more rather than less important. But this was an illusion. Rising productivity and the globalisation of production were in fact undermining its demographic base. Starting in the USA, the UK and Scandinavia, the share of employment in mining and manufacturing began to decline throughout the west (Crouch 1999, ch. 4). The militancy of the 1970s served only to encourage governments that were so inclined to lend their hand to hastening that decline, as occurred in the UK with reference to the coal and some other industries during the 1980s. Industrial workers had never constituted a majority of the working population anywhere, but they had been the growing class; now they were declining. By the 1980s they had been replaced as leaders in industrial militancy by public employees, with whom governments could deal directly without disturbing the market economy much. The main growth sectors of the new economy, private services, were usually not organised and had developed no autonomous political agenda, no organisations to articulate their specific grievances.

In the regime of largely unregulated international finance that was instituted during the 1980s, governments were far more worried about capital movements than labour movements: positively, in that they wanted to attract investment from free-floating capital with short time horizons; negatively in that they feared that such capital would move away if they did not provide conditions in which it was happy.

However, as we have noted, the Keynesian model had met an economic demand from capitalists themselves for stable mass consumption as well as workers' 
demands for stable lives. In the newly industrialising countries of South Asia and the Far East this was not a problem, as these largely undemocratic countries have depended on an extreme form of the export model described above, combined with domestic consumption by wealthy elites. They have not needed spending by the mass of their populations. But this was far from possible in the existing advanced economies. Indeed, dependence there on increased domestic consumption rather than exports had intensified rather than weakened. As the industries making many of the products bought in mass markets moved to new producing countries, or, if they remained, became dependent on less and less labour, employment growth came to depend on markets in personally delivered services, which are not so subject to globalisation. It is easy to buy a Chinese T-shirt in a western shop and benefit from low Chinese wages; it is hardly feasible to travel to China to get a cheap haircut. Immigration is the only way that globalisation affects such services, but its impact is limited by controls of population movements (which have not benefited from market liberalisation but have in general been intensified), and by the fact that immigrants' wages, though usually low, are not as low as in their home countries. So the puzzle remains: if the instability of free markets had to be overcome to usher in the mass consumption economy, how did the latter survive the return of the former?

During the 1980s (or 1990s, depending on when the neo-liberal wave hit a particular economy) the answer first appeared to be a negative one, as rising unemployment and continuing recession became the dominant experience. Then things changed. By the end of the 20th century the UK and the US in particular were demonstrating declining unemployment and strong growth. One explanation might be that, in a really pure market economy, the rapid alternations of boom and bust associated with the earlier history of capitalism do not occur. In the perfect market there is perfect knowledge, rational actors can therefore anticipate perfectly what is going to happen, and can adapt their behaviour to produce a seamless web of adaptation. Did the USA and the UK really enter this nirvana at the turn of the century?

No. Knowledge is far from perfect; exogenous shocks, whether hurricanes, wars or the actions of irrational people who do not behave as theory says they should, continue to impact on economies and to disturb calculations. As we now know, two things came together to rescue the neo-liberal model from the instability that would otherwise have been its fate: the growth of credit markets for poor and middleincome people, and of derivatives and futures markets among the very wealthy. This combination produced a model of privatised Keynesianism (Crouch 2008; Bellofiore and Halevi (forthcoming)) that occurred initially by chance, a real case of market entrepreneurship, but which gradually became a matter for public policy so important as to threaten the entire neo-liberal project.

Instead of governments taking on debt to stimulate the economy, individuals did so. In addition to the housing market there was an extraordinary growth in opportunities for bank loans and credit cards. It was common for people to hold cards from more than one credit card company as well as several store-specific ones.

This explains the great puzzle of the period: how did moderately paid American workers in particular, who have little legal security against instant dismissal from 


\section{Table 1: Mortgages as a Per Cent of Disposable Income (2006), Selected Countries}

\begin{tabular}{lr}
\hline UK & \\
USA & 129.2 \\
Germany & 104.8 \\
Japan & 70.9 \\
Italy & 65.1 \\
& 39.4 \\
\hline
\end{tabular}

Source: OECD Economic Outlook, December 2008

Note: The countries listed were the only ones for which OECD could collect statistics. The Italian figure is for all medium- and long-term loans

their jobs, and salaries that might remain static for several years, maintain consumer confidence, when continental European workers with more-or-less secure jobs and annually rising incomes were bringing their economies to a halt by their unwillingness to spend? US, British and, in particular, Irish (Hay et al. 2008; see also Hay 2009, in this issue) house prices were rising every year; the proportion of the value of the house on which a loan could be raised was also rising until it reached more than 100 per cent; credit card possibilities were growing. With some exceptions European property values remained stable. Mortgage debt reached considerably higher levels in the Anglo-American economies than in typical continental European ones (see Table 1). ${ }^{1}$ Credit card growth was slower in continental Europe. One must recall that in Germany and some other European economies the growth model had never become quite so dependent as the Anglo-American ones on domestic consumer spending. As a result the export-oriented manufacturing sector had remained stronger; government policy was more concerned with keeping export prices low, and less concerned to maintain domestic consumption of locally produced services. In both types of economy public policy was bearing down on wages - in the anglophone countries by reducing collective labour rights that might interfere with markets, in Germany and in some other European countries through the firm anti-inflationary stance of the European Central Bank. Once again, continental European, Japanese and now a wide range of new producers, were dependent on US and to a lesser extent UK consumers buying their goods. But what would enable these consumers to do so? This is where the debt model became so important.

Anti-inflationary policy bears down on the prices of goods and services that lose their value as they are consumed. Producers of food, material goods and services like restaurants or health centres confront an environment hostile to rises in their prices. This is not the case with assets, non-consumables that keep their value after purchase: real property, financial holdings, many art objects. A rise in their price is simultaneously a rise in their value, and does not contribute to inflation. It was seen as an act of political manipulation when the UK government removed mortgage repayments, but not rent, from its calculations of inflation, but it was technically quite correct. Assets, and earnings based on assets, have not been the objects of neo-liberal counter-inflation policy. Therefore, anything that could be switched 
from earnings derived from the sale of normal goods and services to an asset base did very well. This applied to proportions of salaries paid as share options and to spending funded by extended mortgages based on property values rather than by salaries and wages.

Eventually governments, especially British ones, began to incorporate privatised Keynesianism into their public policy thinking, though the phrase did not occur to them. While a reduction in the price of oil would be seen as good news (because it reduced inflationary pressure), a reduction in the price of houses would be seen as a disaster (as it would undermine confidence in debt), and governments would be expected to act through fiscal or other measures to get prices rising again. There had been an initial implicit public policy boost to the model back in the 1980s when the privatisation of council housing enabled large numbers of people on moderate incomes to take on mortgages and, later, to explore the scope for extended mortgages. But the move to more explicit policies to have house prices constantly rising crept up during the first years of the 21 st century until the massive interventions into housing finance and the banking sector in general during 2007 and 2008 (see also Watson 2009, in this issue).

Most of this housing and consumer debt was necessarily unsecured; that was the only way in which privatised Keynesianism could have the same counter-cyclical stimulant effect as the original variety. (For further examples of how unsecured debt can have perverse public policy implications, see Mulligan 2008.) Prudential borrowing against specified collateral would not have helped the moderate-income groups who had to keep spending despite the insecurity of their labour market positions. The possibility of prolonged, widespread unsecured debt was in turn made possible through innovations that had taken place in financial markets, innovations which for a long time had seemed to be an excellent example of how, left to themselves, market actors find creative solutions. Through markets in derivatives and futures the great Anglo-American finance houses learned how to trade in risk. They found they could buy and sell risky holdings provided only that purchasers were confident that they could find further purchasers in turn; and that depended on the same confidence. Provided markets were free from regulation and capable of extensive reach, these trades enabled a very widespread sharing of risk, which made it possible for people to invest in many ventures that would otherwise have seemed unwise (see also Leyshon and French 2009, in this issue). Meanwhile, the liberation of global finance markets brought funds located in ever more extended parts of the world to share the burdens of risk-bearing.

An inability to share risks widely had been at the heart of the economic collapses of 1929 and the 1870s. In the 1940s it had seemed that only state action could solve this problem for the market. But now, absolutely in tune with neo-liberal ideology and expectations, there was a market solution. And, through the links of these new risk markets to ordinary consumers via extended mortgages and credit card debt, the dependence of the capitalist system on rising wages, a welfare state and government demand management that had seemed essential for mass consumer confidence, had been abolished. The bases of prosperity shifted from the social democratic formula of working classes supported by government intervention to the neo-liberal conservative one of banks, stock exchanges and financial markets 
(see also Finlayson 2009, in this issue). This fundamental political shift was more profound than anything that could be produced by alternations between nominally social democratic and neo-liberal conservative parties in government as the result of democratic elections.

\section{After Privatised Keynesianism: The Responsible Corporation?}

But, just as the Keynesian period lasted 30 years from the mid-1940s to the mid-1970s, so the new model underwent a crisis almost exactly 30 years further on that was even more momentous than the collapse of Keynesianism. All theories of market economics depend on the assumption that market actors are perfectly informed, but privatised Keynesianism depended on what were presumed to be the very smartest actors concerned, the financial institutions of Wall Street and the City of London, having highly defective knowledge. More accurately, financial entrepreneurs and accountancy firms developed forms of knowledge that encouraged eventually selfdestructive decisions. This is the Achilles' heel of the model, corresponding to the inflationary ratchet of original Keynesianism. In terms of distributive politics, inflation can be seen as granting many different groups a larger share of the cake by inventing cardboard cake-increases in money values of declining purchasing power. Under privatised Keynesianism vast quantities of totally fictitious cake were produced, on the basis of the notional values of which even vaster quantities of such cake were leveraged. Bad debts were funding bad debts, and so on in an exponentially growing mountain. (For good accounts of this process, see Kay 2009; Wolf 2008.)

As explained above, participation in secondary markets requires concentration on a potentially infinite chain of risk-sharing trades. While in principle the values that individuals in this chain expect those buying from them to estimate are based on the original monetary values of the assets being purchased, in practice they became totally detached from them. Discovering exactly what was contained in a bundle of mortgage and other debts that had been purchased would take time, and time was a highly expensive resource when earnings depended heavily on the velocity with which one could make transactions. Further, risks were being so widely shared that it seemed that little was at stake in any individual transaction. No one had an incentive to take note of the values that assets might possess in the 'real' economy. For markets, which depend on information to function as true markets, to give participants incentives to ignore information is the financial equivalent of those diseases that lead a body's own organs to destroy its immune system.

In an additional twist, information technology, which was supposed to have made it so much easier for market traders to gain information on a global basis, intensified the premium being placed on ignorance. By making transactions so much faster to implement, IT raised the opportunity cost of any detailed searches for complex information, like the composition of a bundle of risks that one was deciding to acquire in a rapidly changing market.

Eventually the ratings agencies, the market's own solution to certifying the quality of financial institutions and indeed national economies, seem to have followed the same path. The fact that the Icelandic banks were being accorded the highest 
possible rating a fortnight before they collapsed suggests that the agencies were not inquiring deeply into the quality of their assets. Aware that the traders in the markets who were using the ratings were not interested in such knowledge, they also ceased to look for it. Instead they followed the judgement of the secondary markets themselves, making a mechanism used for verification dependent for its own information on the activities that they were verifying.

A major step took place when, through the centrality of US stock exchanges, the accounting principles of most major trading countries in the world were pressured into following anglophone approaches to accountancy. These privileged the interests of financial market operators over those of protecting creditors (Botzem and Quack 2006).

Not surprisingly, therefore, when the secondary markets collapsed no one had any idea of exactly how much money had been lost or where it had gone. If the only information that counts is totally reflexive and cannot be validated outside of itself, then information cannot play the role that the market needs it to play. But for so many years no one holding power within or over the system paid any attention to this, despite the strong warning that had been sounded only a few years before when the dot.com bubble burst. Here too asset values had become totally based on an almost infinite regress of expectations of value, gradually losing all touch with what the actual products of Internet-based firms might be. Enthusiasts of that system had believed that they had discovered the holy grail of stock market prices that need never fall; the iron laws of supply and demand had apparently been broken without retribution.

Some people became extremely wealthy in the process, but this does not mean that they were parasites. They continued to be the class whose particular interests represented the general interest, because many people benefited from the growing purchasing power that this system generated. This was true in the UK, USA and one or two other countries where consumer debt fuelled consumption. French, German and most other continental European citizens may feel differently; their financial elites joined in the act, while they experienced little of the growth in credit. On the other hand, their export industries benefited from the continuing capacity of Americans to buy their exports.

Once privatised Keynesianism had become a model of general economic importance, it became a kind of collective good, however nested in private actions it was. Necessary to it was behaviour by banks that has to be defined as irresponsible, as it involved their not carrying out checks and accountancy practices that they were in principle assumed to do. Therefore that very irresponsibility became a collective good. There has been considerable discussion of the serious moral hazards involved in governments coming to the aid of banks that have suffered from this irresponsibility; but there is a far wider moral hazard involved in this complicity of virtually whole societies in the irresponsible practices in the first place.

\section{What Next?}

And so a second regime to reconcile stable mass consumption with the market economy ended. Both Keynesianism and its privatised mutant each lasted 30 years. 
Given the rapidly changing character of capitalist economies, and the absence of any ultimate solution to their need to combine flexible labour and confident consumer, that probably counts as considerable durability. But the question arises: how are capitalism and democracy to be reconciled now? Also, how will the enormous moral hazard established by governments' recognition of financial irresponsibility as a collective good now be managed?

Two things characterised the transition from pre-war economics to Keynesianism and that from original to privatised Keynesianism: the availability of alternative ideas and the existence of a class, the service of whose interests would serve a general interest. It is often claimed that at the present juncture we lack the former (Skidelsky 2009), while no one notices the latter. The absence of ideas is considerably exaggerated in these discussions; the question of a leading class is more important.

Many of the ideas that constituted neo-liberalism had been in existence for more than 200 years when they were refashioned for public policy use during the 1970s. Today many of the components of the much younger mix of Keynesian demand management and neo-corporatism are still around in the economic strategies of small states, usually combined with important elements of neo-liberalism too. Most widely noted, though not unique, is the Danish way (Pedersen et al. 2006) of combining a strong welfare state and powerful trade unions with very flexible labour markets. That seems to square the circle of market flexibility and consumer confidence, as well as powering a dynamic and innovative economy. Different but similar combinations are to be found in the other Nordic countries, the Netherlands (Visser and Hemerijck 1997) and Austria. There is no shortage of policy mixes, but only of coalitions of political forces capable of supporting them in the larger economies; and this returns us to the question of significant social classes.

Economic prosperity continues to depend on supplies of capital through efficient markets far more than it previously depended on the industrial workers of the western world. A difference of geographical reach is part of the explanation. The decline of the western industrial working class does not mean a decline in that class globally. More people are engaged in manufacturing activities today than ever before; but they are divided into national, or at best world regional, lumps with very different histories, cultures, levels of living, organised interests, and trajectories. Finance capital does not come in such parcels but more like a liquid or gas, capable of changing shape and flowing across jurisdictions and regions. We remain dependent on both labour and capital, but the former is subject to divide et imperia, the latter is not-unless we see a major return to economic nationalism and limitations on capital movements that will lead to the break-up of the major corporations that dominate the global economy and probable major economic decline.

The most likely new model is one that in fact depends increasingly on those corporations; the logic of globalisation that imparted an important role to TNCs has not disappeared with the financial system. There has always been a tension at the centre of neo-liberalism: is it about markets or about giant firms? They are far from being the same: the more that a sector is dominated by giant firms, the less it resembles the pure market that in principle lies behind most of today's public policy. There may well be intense competition among giant firms, but it is not the 
competition of the pure market. This is supposed to be characterised by very large numbers of actors, such that each remains incapable of having an effect on prices by its own actions, and certainly incapable of wielding political influence. In the pure market everyone is a price taker; no one a price maker. Neo-liberalism, while it uses the rhetoric of consumer sovereignty and rule by choice expressed through the market, is underpinned by a model of the market economy that is capable of accommodating monopoly power.

While the neo-liberal epoch was just beginning in the mid-1970s, economists at the University of Chicago, the main centre for the generation of neo-liberal ideology, were preparing a new doctrine of competition and monopoly that was soon to influence the US courts, undermining the old principles of anti-trust legislation that had been at the heart of US and, more recently, European competition law. It was not necessary, the doctrine argued, for there to be actual competition for customer welfare to be maximised. Sometimes a monopoly, by its very domination of the market, can offer customers a better deal than a number of competing firms (Bork 1978; Posner 2001). This is not the place to examine the merits of this argument in detail. It is necessary only to understand that neo-liberalism does not share the difficulty that neo-classical economics has with market domination and monopoly capitalism. The recent banking crisis has seen, on both sides of the Atlantic, governments supporting, and gaining the support of competition authorities for, mergers and acquisitions that considerably reduce competition and choice. This remains consistent with dominant interpretations of neo-liberalism, which are in reality more concerned with the firm than with the market.

It is certainly likely that the initial response of governments to the crisis will be a return to strong regulation and even bank nationalisation; these are certainly not consistent with neo-liberalism. However, this is not likely to last. We can anticipate what will happen if we look back to what was in retrospect the first sign that the financial markets were not as effective at automatic self-regulation as was claimed on their behalf: the Enron and WorldCom scandals at the beginning of the century. In its response to these, the US Congress tightened regulations on company auditing in the Sarbanes-Oxley Act. This soon produced complaints from the sector that enterprise was being stifled, and threats that finance houses would leave New York for the more permissive regime in London.

The same will happen after the bout of regulatory measures being visited on the financial sector as part of the deal with governments to save it. How can the derivatives markets get to work in supporting high levels of borrowing if they are to be subject to rules that make much of that borrowing more difficult? Meanwhile, low- and medium-wage, insecure workers will not be able to carry on spending unless they can get their hands on unsecured credit, even if at less frenetic levels than had been occurring. Governments will be concerned to see a return to credit boom as the most effective way of restoring consumer confidence while they continue to pursue policies making labour markets more flexible. Governments will be sympathetic to arguments from the sector that some moderation of regulation will be needed if this is to happen. And individual governments will be tempted to ensure that they have slightly less onerous regulation than the others, in order to attract financial firms to base themselves within their jurisdictions-as the UK has been doing in relation to London for the past 25 years. 
Furthermore, this will be a financial sector with a reduced number of major players, with very easy access to government and often shaped by government itself during the course of the 2008 rescue packages. One further assumes that most governments that have been acquiring banks in the bout of unforeseen nationalisation that followed the October 2008 collapse do not intend to hold on to them according to the old model of controlling the 'commanding heights' of the economy. The fact that big banks operate internationally will itself be a disincentive to that. It is however also unlikely that these banks will be privatised through general public share issues. They will most likely be levered into the hands of a small number of leading existing firms deemed responsible enough to run them in good order. There will overall be a gradual slip towards a more negotiated, voluntary regulatory system. Justified by arguments about flexibility and of reducing burdens on the taxpayer, actual regulation will be exchanged for lightly monitored guarantees of good behaviour by the large financial firms.

To predict this is hardly crystal-ball gazing: it is a general trend in government-firm relations right across the economy. Sharing neo-liberal prejudices against government as such, frightened at the impact of regulation on growth and believing in the superiority of corporate directors over themselves at nearly everything, politicians increasingly rely on corporate social responsibility for the achievement of several policy goals. We should therefore anticipate a shift from unregulated privatised Keynesianism to self-regulated privatised Keynesianism. Some implications of the change have more radical implications. First, the system will less and less be legitimated in terms of the market, freedom of choice and an absence of government involvement. Rather, there will be partnership between government and firms, or autonomous actions by firms commended by governments, with largely informal attempts to reconstruct trust. In some respects this resembles neocorporatism, but with two major differences. First, organised labour will not be present, except as a token actor, as it has little power or competence at the level of global finance. Second, firms participate in corporatist deals as members of associations, which provides something of a level playing field among different companies. Today's global firms have little time for associations, which are mainly nationally based, and seek anything but a level playing field when they build relations with governments. The new 'responsible corporation' model will however resemble corporatism in being limited to nation-state (just possibly EU) level, to which level governments' competence is limited, while the firms remain global and retain a capacity to regime-shop.

Second, this model will see a considerable enhancement of current trends towards a displacement of political activity from parties to civil society organisations and social movements. The model brings firms to prominence, not just as lobbies of governments, but as makers of public policy, either alongside or instead of governments. It will be firms that decide the terms of their codes of behaviour and responsible practices. Firms therefore become political subjects and objects in their own right, ending the sharp separation between governments and private firms that is the hallmark of both neo-liberal and social democratic politics. At the same time, as governments of all parties have to make similar deals with firms, and equally fear for their country's ability to attract liquid capital if they are too demanding of them, differences among parties on core economic policies will shrink 
even further than they have already. Party politics will still have much with which to concern itself: the relative share of public spending; questions of multiculturalism; security. But it will vacate the former heartland of basic economic strategy. In reality it vacated this some years ago in most countries, but shreds of it remain in some parties' rhetoric.

It is already the case that for nearly every major corporation there is a website revealing details of its conduct, assessing its fulfilment of its social responsibility claims. As this remains a no-go area for party conflict, it will grow in importance in civil society politics. It will have the major advantage that it will not be so trapped at the nation-state level as party politics; many of these groups are transnational. But it will be an unsatisfactory politics, as it lacks the formal citizenship egalitarianism of electoral democracy, while retaining many of the bad habits of parties. Activist groups are just as capable of seeking attention with exaggerated claims or (in contrast) developing friendly relations with corporations in exchange for various resources as are parties. It will also be a highly unequal struggle between them and the corporations. The new social movements and civil society organisations, important as they will be to 21 st-century politics, do not constitute a rising new class that stands for a general social interest. They are not a functional interest; they are not deeply rooted within the social structure. The dominant interests of contemporary society remain the great corporations, particularly those in the financial sector. They are currently suffering a loss of face, but both governments and mass prosperity depend on their efficient and lucrative functioning. Any contender for their place as the dominant group within advanced capitalism will have to offer an equivalent centrality.

\section{About the Author}

Colin Crouch, Professor for Governance and Public Management, Warwick Business School, The University of Warwick, Coventry CV4 7AL, UK, email: colin.crouch@wbs.ac.uk

\section{Note}

1. There have been some interesting exceptions. Bohle (forthcoming) describes how Austrian and Swedish banks brought unsecured mortgages to, respectively, Hungary and Latvia, making possible short-lived consumption-led booms.

\section{Bibliography}

Bellofiore, R. and Halevi, J. (forthcoming) 'Deconstructing labor: A Marxian-Kaleckian perspective on what is "new" in contemporary capitalism and economics', in C. Gnos and L.-P. Rochon (eds), Employment, Growth and Development: A Post-Keynesian Approach (Cheltenham: Elgar).

Bohle, D. (forthcoming) 'East European capitalism: What went wrong?', Intervention, 1.

Bork, R. H. (1978) The Antitrust Paradox: A Policy at War with Itself (New York: Free Press).

Botzem, S. and Quack, S. (2006) 'Contested rules and shifting boundaries: International standard-setting in accounting', in M.-L. Djelic and K. Sahlin-Andersson (eds), Transnational Governance: Institutional Dynamics of Regulation (Cambridge: Cambridge University Press), 266-286.

Boyer, R. (2004a) The Future of Economic Growth (Cheltenham: Edward Elgar).

Boyer, R. (2004b) 'New growth regimes, but still institutional diversity', Socio-Economic Review, 2:1, 1-32. 
Boyer, R. (2005) 'From shareholder value to CEO power: The paradox of the 1990s', Competition $\theta$ Change, $9: 1,7-47$.

Crouch, C. (1993) Industrial Relations and European State Traditions (Oxford: Oxford University Press).

Crouch, C. (1999) Social Change in Western Europe (Oxford: Oxford University Press).

Crouch, C. (2008) 'What will follow the demise of privatised Keynesianism?', The Political Quarterly, 79:4, 476-487.

Finlayson, A. (2009) 'Financialisation, financial literacy and asset-based welfare', British Journal of Politics O International Relations, 11:3, 400-421.

Fukuyama, F. (1992) The End of History and the Last Man (London: Hamish Hamilton).

Giddens, A. (1998) The Third Way: The Renewal of Social Democracy (Cambridge: Polity Press).

Hay, C. (2009) 'Good inflation, bad inflation: The housing boom, economic growth and the disaggregation of inflationary preferences in the UK and Ireland', British Journal of Politics $\theta$ International Relations, $11: 3,461-478$.

Hay, C., Riiheläinen, J. M., Smith, N. J. and Watson, M. (2008) 'Ireland: The outlier inside', in K. Dyson (ed.), The Euro at Ten: Europeanisation, Power and Convergence (Oxford: Oxford University Press), 182203.

Kay, J. (2009) The Long and the Short of It (London: The Erasmus Press).

Lehmbruch, G. and Schmitter, P. C. (eds) (1982) Patterns of Corporatist Policy-Making (London: Sage).

Leyshon, A. and French, S. (2009) "We all live in a Robbie Fowler house": The geographies of the buy to let market in the UK', British Journal of Politics $\theta$ International Relations, 11:3, 438-460.

Mulligan, C. B. (2008) A Depressing Scenario: Mortgage Debt Becomes Unemployment Insurance, NBER Working Paper 14514 (Cambridge, MA: National Bureau of Economic Research).

North, D. C. (1990) Institutions, Institutional Change, and Economic Performance (Cambridge: Cambridge University Press).

OECD (2008) OECD Economic Outlook (84 vols) (Paris: OECD).

OECD (2009) 'Growing unequal? Income distribution and poverty in OECD countries'. Available online at: http://www.oecd.org/els/social/inequality

Pedersen, O. K., Campbell, J. L. and Hall, J. A. (eds) (2006) National Identity and Varieties of Capitalism: The Danish Experience (Montreal and Copenhagen: McGill-Queens University Press and Jurist-og Økonomforbundets Forlag).

Posner, R. A. (2001) Anti-Trust Law (2nd edn) (Chicago, IL: University of Chicago Press).

Skidelsky, R. (2009) 'Where do we go from here?', Prospect, 154, 36-40.

Traxler, F., Blaschke, S. and Kittel, B. (2001) National Labour Relations in Internationalized Markets (Oxford: Oxford University Press).

Visser, J. and Hemerijck, A. (1997) A Dutch Miracle: Job Growth, Welfare Reform and Corporatism in the Netherlands (Amsterdam: Amsterdam University Press).

Watson, M. (2009) 'Headlong into the Polanyian dilemma: The impact of middle-class moral panic on the British government's response to the sub-prime crisis', British Journal of Politics $\theta$ International Relations, $11: 3,422-437$.

Wensley, R. (forthcoming) 'Market ideology, globalization and neoliberalism', in P. Maclaran, M. Saren, B. Stern and M. Tadajewski (eds), The Handbook of Marketing Theory (London: Sage).

Wolf, M. (2008) Fixing Global Finance (Baltimore, MD: John Hopkins University Press). 